\title{
EVALUATION OF PROBIOTIC AND ANTIMICROBIAL PROPERTIES OF LACTOBACILLUS STRAINS ISOLATED FROM DAIRY PRODUCTS
}

\author{
DEBAPRIYA MOHANTY*1, PRATIMA RAY1 \\ ${ }^{1}$ Department of Microbiology, Orissa University of Agriculture and Technology, Bhubaneswar, Odisha 751003, India \\ Email: debapriyam.h@gmail.com
}

Received: 08 May 2016 Revised and Accepted: 09 Sep 2016

\begin{abstract}
Objective: Evaluation of antimicrobial efficacy of probiotic Lactobacillus strains isolated from dairy products.

Methods: The study used yogurt sample prepared from raw buffalo milk to isolate Lactobacillus strains by following pour plate technique. All isolated Lactobacillus strains were systematically screened for their probiotic attributes. Here, functional criteria studies for successful probiotics mainly included survival ability of the strains. The capability of the selected Lactobacillus isolates to inhibit the growth of several pathogens was evaluated by the well diffusion method. Based on phenotypic characteristics, biochemical tests and of $16 \mathrm{~S}$ rDNA sequence analysis, the potent probiotic strain was identified. Further study was emphasized on its optimum parameters required for its growth. Again, its activity was characterized with respect to $\mathrm{pH}, \mathrm{NaCl}$ and thermal stability along with susceptibility to enzymes.
\end{abstract}

Results: A preliminary subtractive screening based on antimicrobial potency and probiotic properties revealed the maximum effectiveness of Lactobacillus DM 69 among all and it was identified as Lactobacillus plantarum. The inhibitory substance obtained from DM 69 was relatively heat stable and active under acidic conditions. No susceptibility was found in the presence of $\alpha$-amylase, lipase and lysozyme.

Conclusion: Excellent probiotic and an antimicrobial strain was isolated from buffalo milk and can be formulated and developed as a good nutraceutical food supplement.

Keywords: Lactobacillus species, Probiotic properties, Antimicrobial activity

(C) 2016 The Authors. Published by Innovare Academic Sciences Pvt Ltd. This is an open access article under the CC BY license (http://creativecommons.org/licenses/by/4. 0/) DOI: http://dx.doi.org/10.22159/ijpps.2016v8i11.12683

\section{INTRODUCTION}

Probiotics are increasingly seeking the special interest of health conscious consumers because of their clinical properties and basic nutritional value. Therefore, food and pharmaceutical markets have been introduced by a large number of such health beneficial food components worldwide [1]. Over the years, many potential microbial strains have been used as probiotic cultures mainly including lactic acid producing bacteria, namely, Lactobacillus and Bifidobacterium [2]. Probiotics lactic acid bacteria (LAB) have a long history of safe use [3]. During the selection of Probiotic strains, certain important attributes must be assessed for their commercial uses [4]. The FAO/WHO [5] guidelines propose that the potential probiotic strains should be relevant for surviving in the GIT at the time of ingestion to confer health benefits. Therefore, these properties have consequently become important selection criteria that explain the ability of probiotic strains to tolerate physiochemical harsh environment such as highly acidic conditions present in the stomach and concentrations of bile salts found in the small intestine [6]. In addition, it is essential for probiotic strains to adhere and subsequently colonize the intestinal tract. Adherent ability of probiotic strains has increased the opportunity to colonize the GIT, or else the flow of gut digesta may wash out any bacterium which is not attached to intestinal mucosa [6]. Probiotic strains may act via several mechanisms such as the production of antimicrobial compounds, competitive exclusion, enhancement of intestinal barrier function and immune-modulation, etc to show their beneficial effects on host health $[7,8-10,11]$. Probiotics play a crucial role in prevention and alleviation symptoms of intestinal infections, traveler's diarrhea and antibiotic-associated diarrhea, inflammatory bowel disease, prevention of colon cancer, etc [12]. Again, they are also widely used as a therapeutic agent for treatment of several enteric infections and gastroenteritis caused by various pathogens like Escherichia coli, Bacillus, Salmonella, Shigella, Vibrio cholera, Klebsiella and Pseudomonas [13]. Among Lactobacillus strains, Lactobacillus brevis, L. bulgaricus, L. lactis, L. fermentum, L. acidophilus, L. pentosus, L. rhamnosus and L. plantarum are commonly used as probiotics with various biological applications $[14,15]$. Probiotic bacteria beneficially improve microbiota balance in GIT to counteract local immunological dysfunction, stabilize the intestinal mucosal barrier function and prevent pathogen proliferation and function. In a climate of increasing consumer awareness that diet and health are linked, many researchers in the field are gradually accepting the idea that probiotics will become an alternative treatment to minimize health issues in a natural way.

\section{MATERIALS AND METHODS}

\section{Sampling and isolation}

Representative dairy samples especially yogurt of raw buffalo milk were collected from rural regions of Odisha for the isolation of potentially probiotic Lactobacillus species. The samples were diluted in $0.89 \%$ of saline water and again serially diluted up to $10^{-7}$. Appropriate dilutions were pour-plated using selective media de Man Rogosa and Sharpe (MRS) agar (Hi-media, India Pvt. Ltd.) and incubated at $37{ }^{\circ} \mathrm{C}$ for $24-48$ $h^{*}$. The typical colonies of isolates were randomly selected from MRS plates by observing their colonial morphology [16].

\section{Preliminary Identification of the Lactobacillus species}

Preliminary identification of Lactobacillus species were performed as per Bergey's Manual of Systematic Bacteriology. Gram variability (Gram's reaction), cell morphology, motility, endospore formation, catalase and oxidase reactions of all isolates were tested as per standardized protocols. Endospore formation of all the strains was screened by using Schaffer-Fulton spore stain kit (Hi-media, India Pvt. Ltd.).

\section{Screening of Lactobacilli isolates for their probiotic attributes}

\section{$A$. Tolerance to acidic $\mathrm{pH}$ and bile salt}

The ability of the organisms to survive in the adverse conditions such as low $\mathrm{pH}$ and high bile salt concentration were assessed by inoculating the organisms in MRS broth culture in the presence of 
these adverse influences. Acid tolerance capability of all Lactobacillus isolates was evaluated in MRS broth by adjusting its $\mathrm{pH}$ in different values $(2.0,2.5$ and 3.0) with $1 \mathrm{~N} \mathrm{HCl}$ as per standardized protocol. Similarly, bile salt tolerance of Lactobacillus cultures was examined by inoculating them in MRS broth containing bile salts at the concentrations of $0.3,0.6 \%$ and $1 \%(\mathrm{w} / \mathrm{v}$ ) (Hi-Media, India Pvt. Ltd.). All the broth tubes with different $\mathrm{pH}$ values and bile salt concentration were inoculated with an adequate amount of cultures and furthermore, $1 \mathrm{ml}$ of culture was immediately taken from each tube after an interval of 0,1 and $2 \mathrm{~h}$. The samples were plated onto MRS agar and incubated for $24 \mathrm{~h}$ at $37^{\circ} \mathrm{C}$. After incubation, the viability of bacterial cells was assessed by colony counts (CFU/ml) on the plates to estimate the percentage of acid and bile salt tolerance ability of isolates [17]. Each experiment was carried out in triplicate.

\section{$B$. Bile salt hydrolase (BSH)}

The activity was screened by spotting $20 \mu \mathrm{l}$ of freshly grown cultures on the surface of MRS agar plates supplemented with $0.5 \%(\mathrm{w} / \mathrm{v})$ bile (sodium cholate) (Hi-Media, India Pvt. Ltd.) and $0.37 \mathrm{~g} / \mathrm{l}$ of $\mathrm{CaCl}_{2}$. Then the plates were sealed with parafilm and incubated anaerobically at $37{ }^{\circ} \mathrm{C}$ for 3-4 d. Bsh activity was indicated by deposition of hydrolyzed product in and around the colonies. The presence of inhibition zone around colonies or white opaque colonies indicated BSH activity where negative control was a Lactobacillus strain without BSH activity [18].

\section{In vitro resistance to gastrointestinal conditions}

The strains were inoculated in $10 \mathrm{ml}$ of simulated gastric juice $(6.2$ $\mathrm{g} / \mathrm{l} \mathrm{NaCl}, 2.2 \mathrm{~g} / \mathrm{l} \mathrm{KCl}, 0.22 \mathrm{~g} / \mathrm{l} \mathrm{CaCl}_{2}, 1.2 \mathrm{~g} / 1 \mathrm{NaHCO}_{3}, 0.3 \%$ pepsin, and $\mathrm{pH}$ 3.0) and incubated at $37{ }^{\circ} \mathrm{C}$ in a water bath to simulate peristalsis. After $2 \mathrm{~h}, 17.5 \mathrm{ml}$ of synthetic duodenum juice $\left(6.4 \mathrm{~g} / \mathrm{l} \mathrm{NaHCO}_{3}\right.$, $0.239 \mathrm{~g} / \mathrm{l} \mathrm{KCl}, 1.28 \mathrm{~g} / \mathrm{l} \mathrm{NaCl}$, and $0.1 \%$ pancreatin), adjusted to $\mathrm{pH}$ 7.4 with $5 \mathrm{M} \mathrm{HCl}$, and $4 \mathrm{ml}$ of $10 \%$ (w/v) oxgall (Sigma) were added to the cell suspensions to simulate passage into the upper intestinal tract. After $2 \mathrm{~h}$ of incubation, the survival rate was determined by the plate method using MRS incubated at $37^{\circ} \mathrm{C}$ for $48 \mathrm{~h}$ [20].

\section{$D$. Growth in the presence of lysozyme}

The effect of lysozyme on the growth of probiotic strains could be safety criteria during its evaluation. Freshly grown bacterial cells were removed by centrifugation, pellets were washed and resuspended with phosphate buffer $(0.1 \mathrm{M}, \mathrm{pH} 7.0)$. $1 \mathrm{ml}$ culture of the same isolates was inoculated in electrolyte sterile solution consisting of $0.22 \mathrm{~g} / \mathrm{l} \mathrm{CaCl}_{2} ; 6.2 \mathrm{~g} / \mathrm{l} \mathrm{NaCl}, 2.2 \mathrm{~g} / \mathrm{l} \mathrm{KCl}, 1.2 \mathrm{~g} / \mathrm{l} \mathrm{NaHCO}{ }_{3}$ in the presence of $100 \mathrm{mg} / \mathrm{l}$ of lysozyme (Hi-Media, India Pvt. Ltd.). Samples were incubated at $37^{\circ} \mathrm{C}$ for 30 and $120 \mathrm{~min}$. After incubation, the viability of bacterial cells was assessed by colony counts $(\mathrm{CFU} / \mathrm{ml})$ on the plates to estimate the percentage of lysozyme tolerance potency of the strains [21].

\section{Antagonistic activity against pathogens (Well diffusion method)}

The antagonistic profile of probiotic Lactobacillus species against different pathogens following well diffusion method was reported in several literatures $[17,21]$. In the present study, whole cells of all probiotic isolates and their cell free supernatant (CFS) were taken for consideration to evaluate the total antibacterial activity of probiotic strains. $24 \mathrm{~h}$ grown cultures were centrifuged at $8000 \mathrm{rpm}$ for $20 \mathrm{~min}$ and the supernatants were collected, heated at $80{ }^{\circ} \mathrm{C}$ to inactivate the culture. It was then filtered through a sterilized 0.22 $\mu \mathrm{m}$ MILLEX-GP filter, PES membrane (Millipore, Ireland) and stored at $4{ }^{\circ} \mathrm{C}$ for further use. The antibacterial property of all isolated probiotic Lactobacillus was evaluated against different pathogens such as Bacillus cereus ATCC 10702, Staphylococcus aureus subsp. aureus ATCC 29213, Staphylococcus aureus MTCC 902, Pseudomonas aeruginosa MTCC 741 and Klebsiella pneumonia MTCC 109 by agarwell-diffusion method. All Pathogenic isolates were lawn cultured over MHA plates and the holes of $0.7 \mathrm{~mm}$ diameter were bored on a plate with the help of pipette tips $(100 \mu \mathrm{l}$, diameter $0.7 \mathrm{~cm})$. Then $100 \mu \mathrm{l}$ of prepared samples were added into the well, and the plates were kept at $37^{\circ} \mathrm{C}$ for $24 \mathrm{~h}$ in an upright position, and the diameter of the zone of inhibition was measured. Each experiment was carried out in triplicate.

\section{Molecular identification of the potent probiotic Lactobacillus strain}

The molecular identification by means of $16 \mathrm{~S}$ rDNA-based genus-PCR was performed to amplify the desired amplicon of $795 \mathrm{bp}$ specific for the genus Lactobacillus for only potent strains. The 16S rDNA was amplified from the isolated genomic DNA of potent strain by using forward and reverse primers $16 \mathrm{~S}^{1}$ (5'-AGAGTTT-GATCCTGGCTCAG-3') and $16 \mathrm{~S}^{2}$ (5'-ACGGCTACCTTGTTACGACTT-3'). Homologous sequence identification of the isolate was done by BLASTN (https://blast.ncbi. nlm.nih.gov/Blast.cgi) in NCBI web server.

\section{Biochemical characterization}

Biochemical characterization of potent probiotic strain was performed with a number of testes including carbohydrate fermentation, nitrate reduction, citrate test, and indole test along with MR-VP test. Carbohydrates (glucose, lactose, xylose, maltose, fructose, dextrose, galactose, riffinose, trehalose, melibiose, sucrose, arabinose, mannose, sorbitol, mannitol and arabitol) utilization capacity of potent probiotic strain was determined by using Hi-carbo KIT A and B (Hi-Media, India Pvt. Ltd.). $\mathrm{CO}_{2}$ production from glucose determines the homefermentative and heterofermentative characterization of isolates. MRS broths were inoculated with $1 \%$ fresh overnight cultures and inverted Durham tubes. They were incubated for 5 days at $37^{\circ} \mathrm{C}$ to observe bubble formation which indicates the positive result of the test. In the case of arginine hydrolysis test, arginine MRS medium and Nessler's reagent were used in order to see ammonia production from arginine. Bright orange color indicated a positive reaction while yellow indicated the negative reaction [22].

Evaluation of physiological parameters for optimal growth of potent strains (temperature, $\mathrm{pH}, \mathrm{NaCl}$ and time)

Potent probiotic Lactobabillus isolate was screened to evaluate optimum parameters for its growth. It is allowed to grow in $10 \mathrm{ml}$ MRS broth taken in a different test tube at various temperatures like $4{ }^{\circ} \mathrm{C}, 30^{\circ} \mathrm{C}, 37^{\circ} \mathrm{C}, 44^{\circ} \mathrm{C}, 51^{\circ} \mathrm{C}$ for $24 \mathrm{~h}$ and its optimum temperature was determined by spectrophotometer reading (optical density) at $600 \mathrm{~nm}$. Again, the evaluation of optimum $\mathrm{pH}$ and salinity of the strain for its cultivation was performed by standard protocol. The potent probiotic isolate was cultivated on liquid MRS medium with different $\mathrm{pH}$ conditions (1.5-8.5) and $\mathrm{NaCl}$ concentrations (1-6\%) separately and incubated for $24 \mathrm{~h}$ at $37{ }^{\circ} \mathrm{C}$. Then the bacterial growth was measured by using a spectrophotometer (OD) at 600 $\mathrm{nm}$. Regarding time, the growth pattern of the potent one was studied in MRS broth by inoculating $1 \%$ of the culture. At each time interval, an aliquot of the sample was taken till $72 \mathrm{~h}$ for its respective optical density at $600 \mathrm{~nm}$ [22].

\section{Characteristics of the crude antimicrobial compound}

A sample of the crude antimicrobial compound (cell free supernatant) of potent strain was used for these tests. It was characterized with respect to $\mathrm{pH}, \mathrm{NaCl}$ and thermal stability, susceptibility to denaturation by enzymes and final the antimicrobial activity against different bacteria.

\section{A. Heat resistance}

The cell free supernatant (CFS) exposed to heat treatments in a water bath at $60,70,80,90$, and $100{ }^{\circ} \mathrm{C}$ for $10,30,45$ and $60 \mathrm{~min}$. Then immediately cooled by cold water and tested for remaining antimicrobial activity $[23,24]$.

\section{B. pH sensitivity}

A sample was adjusted to various $\mathrm{pH}$ values in the range of 2-12 with sterile $\mathrm{NaOH}(3 \mathrm{M})$ or $\mathrm{HCl}(3 \mathrm{M})$ and were incubated at $37^{\circ} \mathrm{C}$ for $30 \mathrm{~min}$ then re-adjusted to $\mathrm{pH}$ 6.5. They were further tested for antimicrobial activities by the spoton-lawn method [23, 24].

\section{Enzyme treatments}

Susceptibility to various proteases was performed by incubating the crude in the presence of pepsin $(1 \mathrm{mg} / \mathrm{ml}), \alpha$-Amylase $(1 \mathrm{mg} / \mathrm{ml})$, lipase $(1 \mathrm{mg} / \mathrm{ml})$ and lysozyme $(1 \mathrm{mg} / \mathrm{ml})$ (Hi-Media, India Pvt. Ltd.) at $37^{\circ} \mathrm{C}$ for $2 \mathrm{~h}$. After incubation, the enzymes were inactivated by heat treatment at $65{ }^{\circ} \mathrm{C}$ for $30 \mathrm{~min}$ and tested for antimicrobial activity $[23,24]$. 


\section{Statistical analysis}

The data recorded during the course of the investigation were subjected to significance testing using mean \pm standard deviation (SD) analysis. Statistical significance was set at $\mathrm{P}<0.05$. Results were denoted as mean \pm standard deviation (SD) of triplicate experiments.

\section{RESULTS}

\section{Preliminary identification of indigenous Lactobacilli isolates}

A number of 24 strains were preliminarily isolated from yogurt of buffalo milk by using MRS medium at $37^{\circ} \mathrm{C}$. Out of which, 18 isolates were identified as Lactobacillus species on the basis of their morphological characteristics, gram's staining, motility, spore formation, catalase and oxidase reaction performed as per Bergey's manual of systematic bacteriology (1994). On streak plate in MRS agar, the colonies were small, round and appeared whitish. The cells were Gram Positive, non-spore forming, non-motile, very small rods (cocobacilli) that occurred singly or in pairs. They were facultatively anaerobic, obligately heterofermentative, catalase negative and oxidase positive. The preliminary observation was matched with Bergey's manual of systematic bacteriology, Vol. III, $2^{\text {nd }}$ edition that confirmed all 18 strains were belonging to Lactobacillus species.

\section{Evaluation of Probiotic potential of Lactobacillus isolates}

\section{$A$. Acid and bile salt tolerance}

In the present study, only three strains, namely, DM69, DM71 and DM73 were able to tolerate low $\mathrm{pH}(2,2.5$ and 3$)$ for $2 \mathrm{~h}$ at $37^{\circ} \mathrm{C}$. The viability of those strains was described in the form of log CFU/ml (fig. 1) where the viability of isolates $2,2.5$ and 3 at $\mathrm{pH}$ indicated their good tolerance potency to acidic conditions $[17,25]$. Further, the same three strains showed the viability in the form of $\log \mathrm{CFU} / \mathrm{ml}$ at high bile salt concentration of $0.3 \%, 0.6 \%$ and $1 \%(\mathrm{w} / \mathrm{v})$ till $2 \mathrm{~h}$ that indicated the strains can survive at high bile salt concentration (fig. 2). ANOVA test revealed that a highly significant variation of $\log \mathrm{CFU} / \mathrm{ml}$ values was observed among all the isolates $(\mathrm{P}<0.05)$.

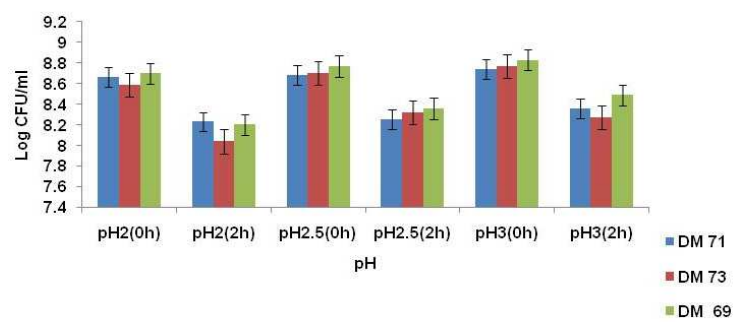

Fig. 1: Acid tolerance capability of isolated Lactobacillus: viability $(\log \mathrm{CFU} / \mathrm{ml})$ of all 3 probiotic strains (DM71, DM73 and DM69) with respect to pH2-3 till $2 \mathrm{~h}$. The results are the means of 3 independent experiments and the bars correspond to standard deviations $(\mathrm{P}<0.05)$

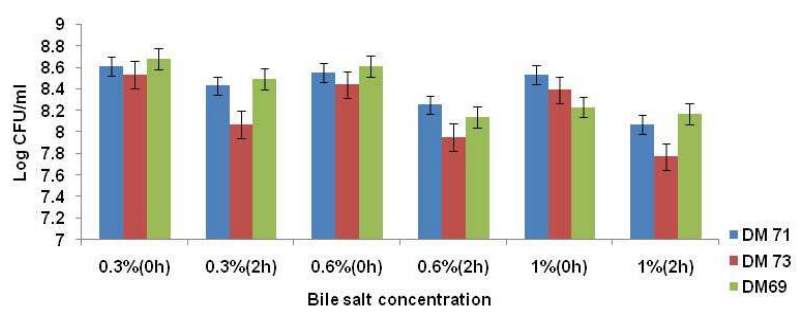

Fig. 2: Bile salt tolerance test: viability $(\log \mathrm{CFU} / \mathrm{ml})$ of probiotic strains (DM71, DM73 and DM69) with respect to various bile salt concentrations $(0.35,0.6 \%$ and $1 \%)$. The results are the means of 3 independent experiments and the bars correspond to standard deviations $(\mathrm{P}<0.05)$

\section{B. Bile salt hydrolase (BSH)}

BSH activity by a probiotic bacterium may be desirable since it increases the intestinal survival and persistence of producing strains. BSH activity is a relevant property for probiotic strains to survive the toxicity of conjugated bile salts in the duodenum [24]. Among all strains, the growth of DM69 along with a zone of salt precipitation around the colonies at the concentration of $5 \%$ could be observed on plates supplemented with sodium cholate. It suggested that the strain produced Bsh activity specific to bile salt (sodium cholate) hydrolysis $[27,29]$

\section{Resistance to gastrointestinal conditions}

Highly potent probiotic strains would have the ability to resist gastrointestinal fluid and should able to grow in the proximal small intestine in the presence of pancreatin and bile salts $(0.15-0.30 \%)$. Exposure to gastric and intestinal fluids is the main environmental stress that decreases the viability of ingested probiotics [17]. The survival responses of the strains, after $2 \mathrm{~h}$ of exposure to gastrointestinal condition, only DM 69 and DM 71 showed their viability. In this study, strain DM 69 retained high viability during simulated artificial gastric juice (pH 3.0) transit for $90 \mathrm{~min}$ and duodenum juice $(\mathrm{pH} \mathrm{8.0)}$. The viability of this strain was described in form of $\log \mathrm{CFU} / \mathrm{ml}$. The initial $\log (\mathrm{CFU} / \mathrm{ml})$ was which 8.1 which decreased to 7.96 after exposing to gastrointestinal juice for $2 \mathrm{~h}$.

\section{$D$. Growth in the presence of lysozyme}

Exposure to internal fluids consisting of lysozyme is the main environmental stress that decreases the viability of ingested probiotics. Furthermore, only DM 69 exhibited survivor counts still higher than $8 \log \mathrm{CFU} / \mathrm{ml}$ after lysozyme treatment for $120 \mathrm{~min}$. A high resistance to presence of lysozyme $(8.36 \mathrm{log} \mathrm{CFU} / \mathrm{ml}$ after 120 $\mathrm{min}$ ) mainly determined its survival capability in GI tract.

\section{Analysis of antagonist effect of probiotic strains}

The present investigation also highlights the antipathogenic effect of DM 69 against Gram-positive and Gram-negative bacteria. Out of all three probiotic strains, the whole cell of DM69 and its cell-free supernatant had antagonistic property towards Bacillus cereus ATCC 10702, Staphylococcus aureus subsp. aureus ATCC 29213, Staphylococcus aureus MTCC 902, Pseudomonas aeruginosa MTCC 741 and Klebsiella pneumonia MTCC 109. It was mainly indicated the presence of an extracellular antimicrobial compound in potent probiotic DM69. The diameter of inhibition zones in well diffusion method was greater than $10 \mathrm{~mm}$ (fig. 3, 4). This result was in agreement with several previous studies [15]. ANOVA test revealed that a highly significant variation of the zone of inhibition values was observed among all the isolates $(\mathrm{P}<0.05)$ against pathogens.

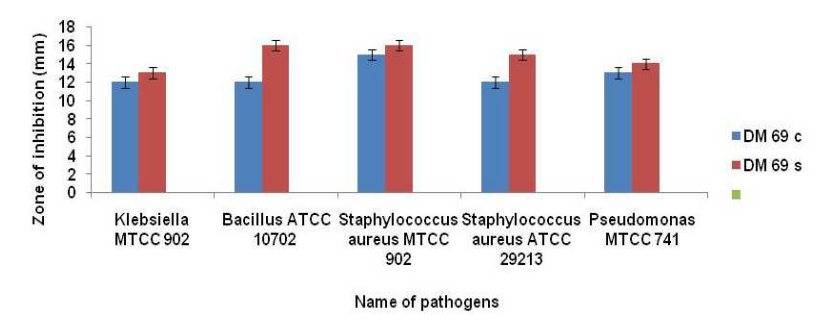

Fig. 3: Zones of inhibition shown by both whole cell (c) DM69 and its CFS (s) against several pathogens. The results are the means of 3 independent experiments and the bars correspond to standard deviations $(\mathrm{P}<0.05)$

\section{Molecular identification and biochemical characterization}

After a couple of screening, DM69 was considered as a potent probiotic Lactobacillus strain (also safe for consumption) along with its antimicrobial activity against various pathogens. Finally, it has been identified in molecular level by $16 \mathrm{~S}$ rDNA sequencing. All the top hits in the BLAST search revealed the highest sequence identity with the L. plantarum with sequence coverage of $99 \%$. The $16 \mathrm{~S} \mathrm{rRNA}$ sequence has been deposited in the Genbank database and got an Accession no KT716348 from NCBI. Again, it was for the characterized by analyzing its sugar utilization pattern. DM69 has 
proven to utilize all sugars such as glucose, lactose, xylose, maltose, fructose, dextrose, galactose, riffinose, trehalose, melibiose, sucrose, arabinose, mannose, sorbitol, mannitol and arabitol. Gas occurrence in Durham tubes was observed during $5 \mathrm{~d}$ which is the evidence for $\mathrm{CO}_{2}$ production from glucose. Strain DM 69 gave the bright yellow which was accepted that they cannot produce ammonia from arginine. Again, it showed negative results in citrate and MR-VP test while positive for nitrate and indole test.

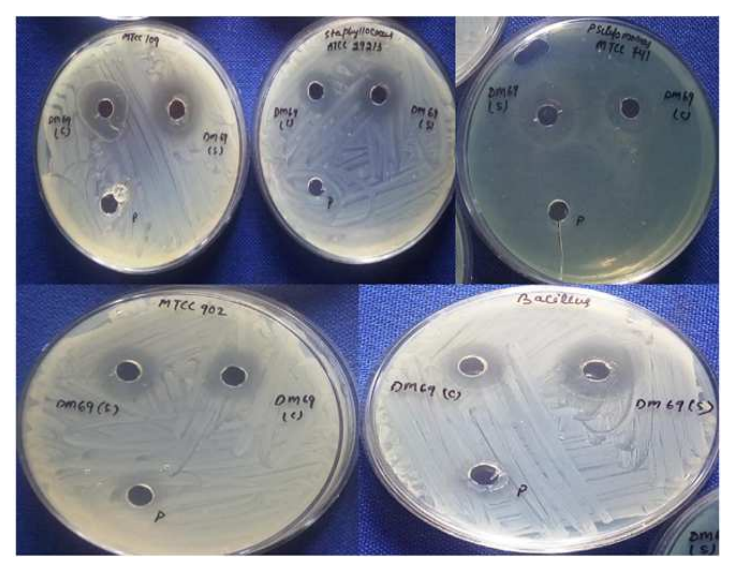

Fig. 4: Zone of inhibitions of DM 69 whole cell (c) and supernatant (s) against pathogens

\section{Effect of physiological parameters for optimal growth of DM69}

In the present study, it could be concluded that the potent probiotic antimicrobial isolate (DM69) was able to grow at 30 and $37{ }^{\circ} \mathrm{C}$ where mild growth was observed at $44{ }^{\circ} \mathrm{C}$ in MRS broth. The optimum $\mathrm{pH}$ for growth of DM69 was obtained at $\mathrm{pH}$ range of 5.5 and 6.5 while growth has not found at very high and low $\mathrm{pH}$. In the case of various concentrations of $\mathrm{NaCl}$ tested from $1-6 \%$, the high level of growth was found between 1 to $2 \%$ where mild growth was observed at $3 \%$. Again, the minimum growth in the presence of $4 \%$ $\mathrm{NaCl}$ indicated that the growth of DM69 decrease with increasing salt concentration. Regarding time effect, an exponential growth was observed till $18 \mathrm{~h}$ after which stationary stage was measured till 42 $\mathrm{h}$ and later cell decline was found (fig. 4) [22].

\section{Characteristics of the crude antimicrobial compound}

The antimicrobial substance produced by DM 69 was considered to be heat stable, as there was no reduction in activity after heat treatment from 60 to $100{ }^{\circ} \mathrm{C}$ for $45 \mathrm{~min}$. the highest antibacterial activity was exhibited in an acidic $\mathrm{pH}$ range of 2-8, while inactivation occurred at $\mathrm{pH} 9$ and 10. The inhibitory substance containing CFS was tested for its sensitivity to various enzymes. It was clear from the experiments that antimicrobial activity was lost or unstable after treatment with pepsin while found to active in the presence of $\alpha$-amylase, lipase and lysozyme [23, 24].

\section{DISCUSSION}

Traditional fermented foods are one of the rich sources for isolation of Lactobacillus strains. In recent years many literatures have been emphasized on isolation, characterization of Lactobacillus strains from traditional fermented foods [17, 25]. Mostly yogurt is a potential source of bioavailable vitamin, minerals with less lactose and galactose than milk [29]. Consumption of yogurt may modulate the immune response in the elderly. These health benefits have been linked to the presence of live bacteria [30]. In the present work, Lactobacillus strains were isolated from fermented dairy products (yogurt prepared from buffalo milk) and were screened to identify a new potential probiotic and antipathogenic strain. The probiotic isolate exhibited the highest antibacterial activity chosen for its further characterization and analysis. The potent probiotic Lactobacillus DM69 was identified as Lactobacillus plantarum by standard biochemical and molecular typing methods. In a similar way, several Lactobacillus plantarum and Lactobacillus paracasei were isolated from buffalo milk as well as Sudanese fermented camel's milk product Garris [17, 31]. The Joint FAO/WHO Working party Report in 2002 [5] suggested that microbes should have a minimum set of characteristics that could predict probiotic potential. Highly potent probiotic strains would have the ability to resist passage through the stomach in the presence of acid $(\mathrm{pH}$ ranges from 1.5 to 3 ), pepsin and lysozyme, and the ability to grow in the proximal small intestine in the presence of pancreatin and bile salts $(0.15-0.30 \%)$. Exposure to gastric and intestinal fluids is the main environmental stress that decreases the viability of ingested probiotics $[32,33]$. It has been already experimentally proved that the food transit time through the human stomach is about $90 \mathrm{~min}$. Therefore, potential probiotic strains must be surviving harsh physicochemical environment up to $90 \mathrm{~min}$ [34]. During a preliminary subtractive screening, though all strains were found with good probiotic properties, the maximum viability was recorded for DM 69 (approximately 8) in low pH and bile salt concentration. Several studies have also shown similar findings with L. plantarum strains, which could tolerate low ( $\mathrm{pH}$ 1.5-3.0), high bile salt concentration (up to $1 \%$ ) along with in vitro resistance to gastric juice. BSH activity is a relevant property for probiotic strains to survive the toxicity of conjugated bile salts in the duodenum [23].

In our study, DM 69 was able to grow in the presence of conjugated bile salts after $48 \mathrm{~h}$ of incubation. It suggested that the strain produced BSH activity specific to bile salt (sodium cholate) hydrolysis. A similar result was also observed by Pisano et al. 2014 [27] and Anas et al. (2014) [28] where they found deposition of sodium cholate indicating a positive result for BSH activity. The present investigation also highlights the antipathogenic effect of DM 69 against Gram-positive and Gram-negative bacteria such as Bacillus cereus ATCC 10702, Staphylococcus aureus subsp. aureus ATCC 29213, Staphylococcus aureus MTCC 902, Pseudomonas aeruginosa MTCC 741, Klebsiela pneumonia MTCC 109. The diameters of inhibition zones observed in well diffusion method were greater than $10 \mathrm{~mm}$. These results indicate that the Lactobacillus species are capable of synthesizing substances inhibiting the growth of pathogenic bacteria. The same antimicrobial study was observed in previous researchers [17, 19] where Lactobacillus species were found to be effective against many grampositive and negative pathogens. Various physicochemical factors seemed to affect the production as well as the activity of the antimicrobial compound. The antimicrobial substance produced by the tested isolate remained fully stable after heat treatment from 60 to $100{ }^{\circ} \mathrm{C}$ for $45 \mathrm{~min}$. Though, such inhibitory substance obtained from lactobacilli are relatively heat stable and relatively active under acidic conditions with promising inhibitory spectra of antimicrobial activities but heat stability and activity at lower $\mathrm{pH}$ values ( $\mathrm{pH} 5$ and below)of bacteriocins produced by Lactobacillus spp has been well established [21, 22]. The completely inactivated inhibitory activity was found in well diffusion assay while CFS treated with pepsin while found to active in the presence of $\alpha$-amylase, lipase, and lysozyme. As a result of our research work, it could be noticed that the strain of Lactobacillus plantarum (DM 69) can be considered as a new probiotic strain along with a strong antipathogenic property against severing disease causing agents.

\section{CONCLUSION}

The use of probiotics for disease control in human is an area of interest in this study. Here, a Lactobacillus plantarum strain isolated from Indian dairy products possesses several good characteristics that make it suitable for use with various probiotic products. It also exhibited broad antimicrobial spectrum against pathogenic bacteria which may possible to conceptualize the use such strains over the antibiotics. From the present investigation on probiotics, it was concluded that buffalo milk probiotics and their antipathogenic live bacteria can be used for oral therapy and as prophylactic to prevent the enteric infections such as diarrhea, gastroenteritis, dysentery, urinary tract infections, food poisoning, typhoid, irritable bowel syndrome etc. Probiotics Lactobacillus DM 69 strain can be used an adjuvant or alternative therapy in gastrointestinal disorders as they are considered effective on human health.

\section{CONFLICT OF INTERESTS}

Declared none 


\section{REFERENCES}

1. Stanton C, Paul Ros R, Fitzgerald GF, Sindern DV. Fermented functional foods based on probiotics and their biogenic metabolites. Curr Opin Biotech 2005;16:198-03.

2. Holzapfel WH, Haberer P, Geisen R, Björkroth J, Schillinger U. Taxonomy and important features of probiotic microorganisms in food and nutrition. Am J Clin Nutr 2001;73:365-73.

3. Salminen S, Von Wright A, Morelli L, Marteau. Demonstration of safety of probiotics a review. Int J Food Microbiol 1998;44:93-106.

4. Sanders ME. Probiotics: definition, Sources, Selection, and Uses. Clin Infect Dis 2008;46:58-61.

5. FAO/WHO. Guidelines for the evaluation of probiotics in foodJoint Food and Agricultural Organization of the United Nations and World Health Organization Working Group Meeting Report, London Ontario, Canada; 2002.

6. Tuomola E, Crittenden R, Playne M, Isolauri E, Salminen S. Quality assurance criteria for probiotic bacteria. Am J Clin Nutr 2001;73:393-8.

7. Smits HH, Engering A, van der Kleij D, de Jong EC. Selective probiotic bacteria induce IL-10-producing regulatory $\mathrm{T}$ cells in vitro by modulating dendritic cell function through dendritic cell-specific intercellular adhesion molecule 3-grabbing nonintegrin. J Allergy Clin Immunol 2005;115:1260-7.

8. Yan F, Cao H, Cover TL, Whitehead R. Soluble proteins produced by probiotic bacteria regulate intestinal epithelial cell survival and growth. Gastroenterology 2007;132:562-75.

9. Borchers AT, Selmi C, Meyers FJ, Keen CL, Gershwin ME. Probiotics and immunity. J Gastroenterol 2009;44:26-46.

10. Collado MC, Meriluoto J, Salminen S. Role of commercial probiotic strains against human pathogen adhesion to intestinal mucus. Lett Appl Microbiol 2007;45:454-60.

11. Servin AL. Antagonistic activities of lactobacilli and bifidobacteria against microbial pathogens. FEMS Microbiol Rev 2004;28:405-40.

12. Wollowski I, Rechkemmer G, Pool-Zobel BL. Protective role of probiotics and prebiotics in colon cancer. Am J Clin Nutr 2001;73:451-5.

13. Ballal M, Shivananda PG. Rotavirus and enteric pathogens in infantile diarrhoea in manipal, South India. Indian J Pediatr 2002;69:393-6.

14. Rejiniemon TS, Rejula HR, Bhamadevi R. In vitro functional properties of Lactobacillus plantarum isolated from fermented ragi malt. South Indian J Biol Sci 2015;1:15-23.

15. Jagadeesh KS. Lactic acid bacteria as a source of functional ingredients. South Indian J Biol Sci 2015;1:70-1.

16. Guessas B, Kihal M. Characterization of lactic acid bacteria isolated from algerian arid zone raw goats' milk. Afr J Biotechnol 2004;3:339-42.

17. Kaushik JK, Kumar A, Duary RK, Mohanty AK, Grover S, Vatish VK. Functional and probiotic attributes of an indigenous isolate of Lactobacillus plantarum. PLoS One 2009;4:e8099.

18. Schillinger U, Guigas C, Holzapfel WH. In vitro adherence and other properties of lactobacilli used in probiotic yoghurt-like products. Int Dairy J 2005;15:1289-97.

19. Fern' Andez MF, Boris S, Barb' Es C. Probiotic properties of human lactobacilli strains to be used in the gastrointestinal tract. J Appl Microbiol 2003;94:449-55.
20. Sharafi H, Alidost L, Lababpour A, Zahiri HS. Antibacterial activity of probiotic Lactobacillus plantarum HK01: effect of divalent metal cations and food additives on production efficiency of antibacterial compounds. Probiotics Antimicrob Proteins 2013;5:121-30.

21. Zinedine A, Faid M. Isolation and characterization of strains of Bifidobacteria with probiotic properties in vitro. World J Dairy Food Sci 2007;2:28-34.

22. Roos S, Engstrand L, Jonsson H. Lactobacillus gastricussp. nov., Lactobacillus antrisp. nov., Lactobacillus kalixensissp. nov. and Lactobacillus ultunensis sp. nov., isolated from human stomach mucosa. Int J Syst Evol Microbiol 2005;55:77-82.

23. Tiwari SK, Srivastava S. Characterization of a bacteriocin from Lactobacillus plantarum strain LR/14. Food Biotechnol 2008;22:247-61.

24. Oh S, Kim SH, Worobo RW. Characterization and purification of a bacteriocin produced by a potential probiotic culture, Lactobacillus acidophilus 30SC. J Dairy Sci 2000;83:2747-52.

25. Tripathy P, Suar M, Das JK, Saini M. Probiotic and functional characteristics of an indigenous Lactobacillus species isolated from the traditional fermented product (Dahi-Chenna) of rural Odisha. Int J Curr Microbiol Appl Sci 2014;3:82-95.

26. De Smet I, Van Hoorde L, Vande Woestyne M, Christiaens H, Verstraete W. Significance of bile salt hydrolytic activities of lactobacilli. J Appl Bacteriol 1995;79:292-301.

27. Pisano MB, Viale S, Conti S, Fadda ME. Preliminary evaluation of probiotic properties of lactobacillus strains isolated from sardinian dairy products. Biomed Res Int 2014. http://dx.doi.org/10.1155/2014/286390.

28. Anas M, Ahmed K, Mebrouk K. Study of the antimicrobial and probiotic effect of Lactobacillus Plantarum isolated from raw goat's milk from the region of Western Algeria. Int J Sci Basic Appl Res 2014;13:18-27.

29. Cano PG, Aguero G, Perdigon G. Immunological effects of yogurt addition to a re-nutrition diet in a malnutrition experimental model. J Dairy Res 2002;69:303-16.

30. Bourlioux P, Pochart P. Nutritional and health properties of yogurt. World Rev Nutr Diet 1998;56:217-58.

31. Sulieman AE, Osawa R, Tsenkova R. Isolation and identification of Lactobacilli from gariss, a sudanese fermented camels milk product. Res J Microbiol 2007;2:125-32.

32. Saarela M, Mogensen G, Fonden R, Matto J, Mattila-Sandholm T. Probiotic bacteria: safety, functional and technological properties. J Biotechnol 2000;84:197-15.

33. Tuomola E, Crittenden R, Playne M, Isolauri E, Salminen S. Quality assurance criteria for probiotic bacteria. Am J Clin Nutr 2001;73:393-8.

34. Begley M, Gahan CG, Hill C. The interaction between bacteria and bile. FEMS Microbiol Rev 2005;4:625-51.

\section{How to cite this article}

- Debapriya Mohanty, Pratima Ray. Evaluation of probiotic and antimicrobial properties of Lactobacillus strains isolated from dairy products. Int J Pharm Pharm Sci 2016;8(11):230-234. 